\title{
A New Learning Space Combining Digital Information and Books: The Case of Seisho-kaichi School
}

\author{
Natsuko Ogawa \\ Seisho-kaichi Junior and Senior High School \\ Tottori Prefecture Tottori City Kokufu Town Shindori 3-301-2 \\ Japan \\ n.ogawa@seishokaichi.ed.jp
}

\begin{abstract}
In Japanese Junior and Senior High schools, books and computers are often tucked away in school libraries or computer rooms, separated from the classroom. Students are left isolated from the tools that stimulate their own learning. I will introduce Seisho-kaichi Junior and Senior High School as a practical example of solving these problems conventional schools have. One of the primary focus of the school is 'building a school in a library'. Books are not all hidden away in the library; rather bookshelves are arranged throughout the school building. Another primary concept is the use of digital tools: the whole school is equipped with wireless internet access, and each student has his or her own tablet computer. The other primary concept is active learning. Seisho-kaichi strongly believes these focuses better equip students to reach their education goals.
\end{abstract}

Keywords: School in library, One Person One Tablet, Active learning

\section{Introduction}

In Japan, MEXT (Ministry of Education, Culture, Sports, Science and Technology) defines the three main roles of the school library as being a reading center, a learning center, and an information center. In this article, l'd like to introduce what kind of problems school libraries in Japan have and how our school library is trying to solve these problems. In particular, we face issues relating to the school library as a learning center and an information center (MEXT, 2015, p.19). 


\section{The problems school libraries in Japan have to solve}

The school library as a learning center should provide appropriate books and materials to support students' learning. Actually, however, many school libraries are not used often enough or effectively.

The Tottori Prefectural Library conducted a survey of librarian-teachers working at both public and private junior high schools in Tottori Prefecture (Tottori Prefectural Library, 2016, p.12). $39 \%$ of these librarian-teachers responded that their libraries are poorly equipped and students don't know how to use them efficiently. Comments included: "School libraries are not well-equipped enough for the lessons (too small, too old, or don't have desks nor blackboards)," "It takes too much time to prepare and conduct lessons with the library," and "It's hard to use the ICT (Information and Communications Technology)."

On the other hand, the school library as an information center should educate students to utilize information effectively, especially in this knowledge-based society. Yet, unfortunately, students in Japan have almost no opportunity to use ICT devices during lessons. OECD (the Organization for Economic Co-operation and Development) surveyed 15-year-old school pupils about computer use during math, science, and reading lessons (NIER, 2010, p.55). Among the 19 countries that participated in PISA2009 (Program for International Student Assessment), Japan had the lowest ratio of students using a computer during math, science, and reading lessons. Only $1.3 \%$ of students used an ICT device for math, $1.6 \%$ for science, and $1.0 \%$ for reading.

JAPET (Japan Association for Promotion of Educational Technology) and Microsoft Japan Co., Ltd. also surveyed teachers of the five subjects - Japanese, math, social studies, English, and science - all over Japan on the use of ICT at school (JAPET, 2011, pp. 30-31). Public and private elementary, junior high, high and special needs schools were included. $48.8 \%$ junior high school teachers and $41.5 \%$ high school teachers said that combining lessons with ICT was difficult because of timing issues. Preparation such as moving to computer rooms and starting up computers severely cut into class time.

$42.2 \%$ of junior high school teachers and $32.6 \%$ of high school teachers said that their schools don't have enough PCs and tablets. Moreover, $74.0 \%$ of junior high school teachers and $63.2 \%$ of high school teachers said that the reason why the students are less likely to use ICT during lessons is because ICT devices are isolated in areas such as the computer rooms. According a survey by MEXT of all school libraries in Japan, only $37.9 \%$ of junior high schools and $66.8 \%$ of high schools provide available computers to students in the library (MEXT, 2015, p.8). Naturally this results in far fewer lessons with ICT devices and school library together.

A lack of specialists is another big problem for school libraries in Japan. 'The School 
Library Act' defines "Shisho-kyoyu," which literally means the librarian-teacher, as 'those who are in charge of school library professionally,' and "Gakko-shisho," which literally means the school librarian, as 'those who work at a school library' (School Library Act 1953, art.5 and art.6). On this point, you may be confused about the difference between two of them, but there is a clear difference in Japan that "Shisho-kyoyu" as the librarian-teacher must be qualified as a teacher and "Gakko-shisho" as the school librarian isn't qualified as a teacher.

There are issues that arise with both. There are two potential problems with the librarian-teacher. The first is "how much of a librarian is a librarian-teacher, really?" With only ten credits at university, aspiring teachers can get a librarian-teacher license. Some of them can receive a license with less than ten because they have library experience.

The second issue is that the librarian-teacher cannot give all of his or her work time to the school library. 'The School Library Act' says "The librarian-teacher job should be assigned to a senior teacher or teachers." Seniority means librarian-teachers are usually extremely busy with teaching their subject or holding homeroom teacher positions, so that they cannot do their job as a librarian-teacher well. (In Japan, homeroom teachers have many duties, including disciplining their class' students for behavior in any subject, eating lunch with students, visiting parents' houses, and many more.)

In $2007,80 \%$ of the librarian-teachers held two posts concurrently as a librarian-teacher and a homeroom teacher (Kowata, 2011, p.15). Moreover, although the revised School Library Act (as cited in ?, 2014) obligates schools to have a school librarian, it only targets schools that have more than 12 classes, which is around 480 students. Thus, $97.2 \%$ of such junior high schools and $93.0 \%$ of high schools can have a librarian-teacher, but this figure drops down to $62.6 \%$ of junior highs and $81.4 \%$ of high schools when schools with less than 12 classes are included (MEXT, 2015, p.2)

There are two potential problems with the school librarian post. First, the post of "school librarian" in Japan has no set requirements. When we call a person 'a school librarian', some of these individuals have library qualifications, which demands 32 credits at university. However, other school librarians have no professional library knowledge or experience.

The school also just needs to make 'a reasonable effort' to hire a librarian. As a result, only $53.1 \%$ of junior high schools and $64.4 \%$ of high schools have them (MEXT, 2015, p.5).

The second issue is that this school librarian isn't necessarily a full-time worker. Many are part-time or volunteers. Therefore, it's almost impossible for them to support students whenever students need them, or cooperate closely with teachers. In comparison to the United States, which establishes the school librarian as a media specialist (Oshiro, 2010, p.12), it is clear that library expertise is lacking in Japanese schools. 
There are three problems Japanese school libraries face: segregated classroom and resource spaces, ICT devices and human resources. In this article, I will introduce Seisho-kaichi Junior and Senior High School, which opened in 2014 in Tottori Prefecture of Japan, as an example of an integrated learning space to solve these problems.

\section{School space harmonized with both library and ICT}

As I mentioned above, in Japanese junior and senior high schools, libraries or computer rooms are often separated from the classroom. It's difficult for teachers to promote students' interest in these critical tools. Furthermore, when developing a research-based program of study, students require a learning space that is not only connected to the internet, but also that promotes group co-operation. However, in the traditional school layout, students are left isolated from the tools that stimulate their own learning. The current situation in schools doesn't meet the needs of the modern student. An integrated learning space will help solve these problems that conventional Japanese schools have.

One of the primary concepts of Seisho-kaichi is 'a school inside a library'. In order to harmonize 'the library' and 'the computer room' with 'classrooms,' bookshelves are arranged throughout the school building, essentially making the building a library in itself. Moreover, the whole school is equipped with wireless internet access, and each student has his or her own tablet computer. They are freely able to access books and digital information anywhere in the school, at any time. This results in students being more actively involved and interested in their own learning. Especially in research-based learning, students should have seamless access to all resources available to them, and an environment where they can share and process that information together. Seisho-kaichi was built around the idea of that environment.

\subsection{A School Inside a Library}

John Dewey shows the shape (the left of Diagram1) of his ideal school concept (Dewey, 1957, p.96). In his book, the library - the symbol of logic - is located in the center of the building and surrounded by the shop, the textile industries, the dining room and the kitchen symbols of practice. As a result, logical spaces and practical spaces are organically connected. 
School

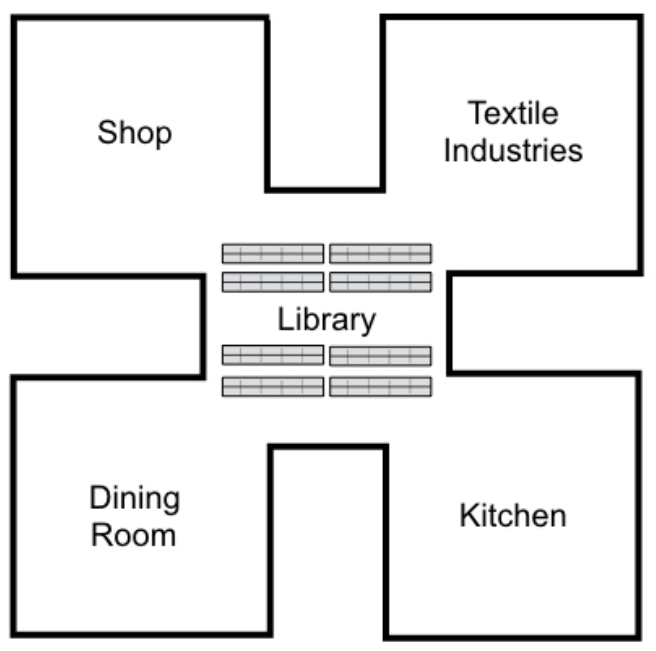

$\rightleftarrows$ : Image of Bookshelves
School in Library

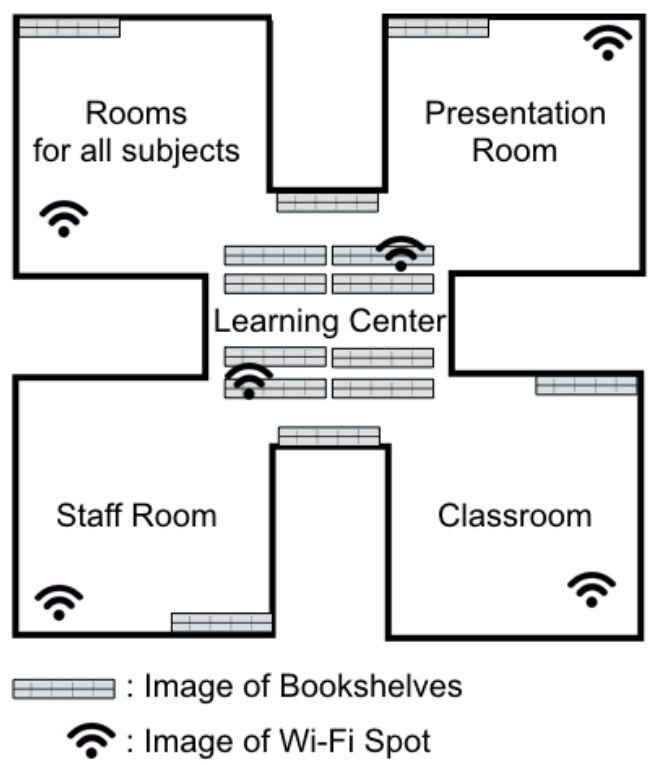

Diagram 1

Seisho-kaichi expands his theory further by putting books literally everywhere (the right of Diagram 1). Books are not only in the library but also in the classrooms, the corridors and even in the principal's office. This makes Seisho-kaichi less of a school with a library and more 'a school inside a library'.

Diagram 2 shows the layout of Seisho-kaichi. Bookshelves are arranged throughout the school building, from the center of the school outward. The learning center is fully equipped for students' learning with movable tables and chairs, a movable whiteboard and bookshelves. 

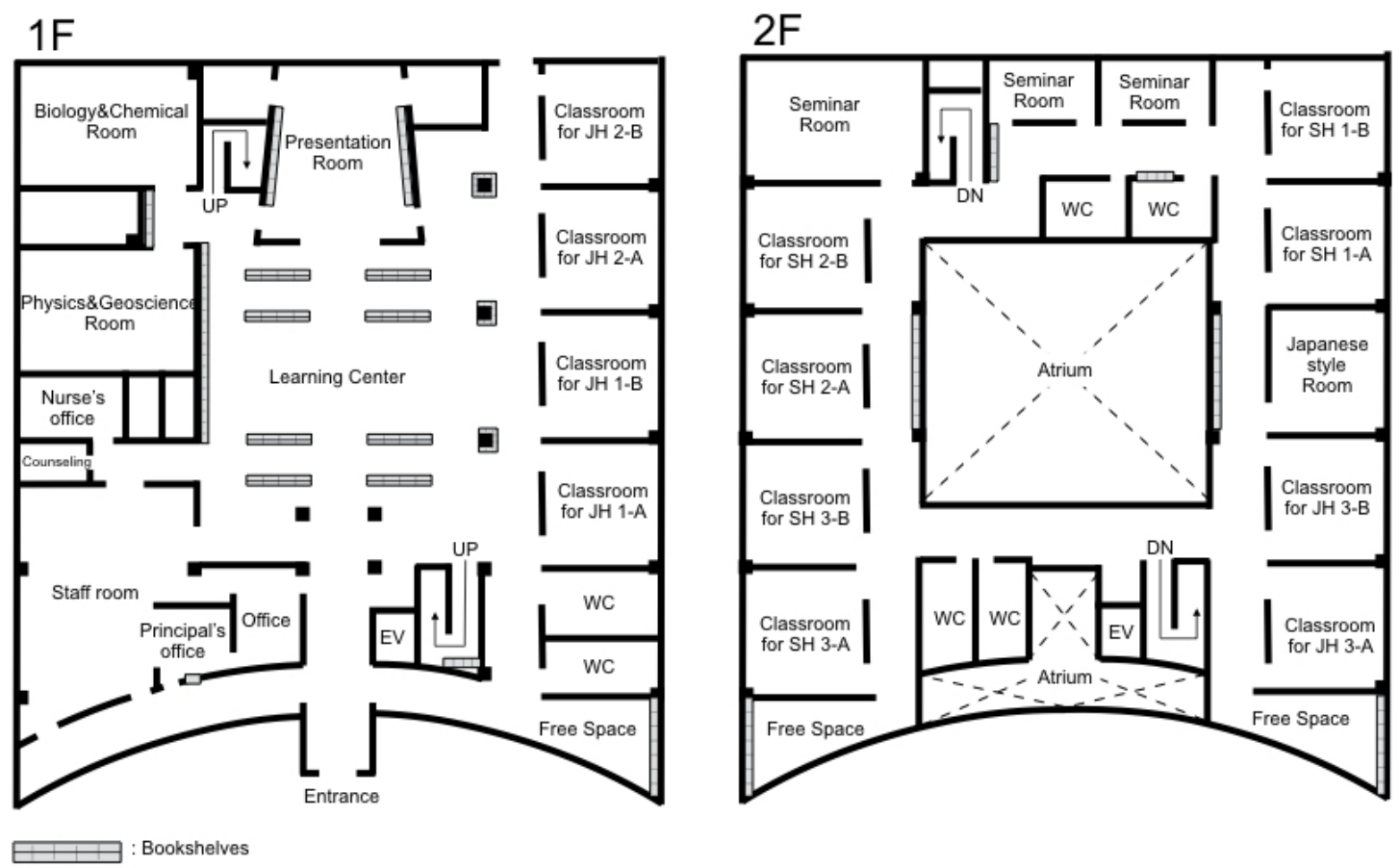

Diagram 2

The learning center can hold 20,000 books, and the whole school building can hold 27,000 books. Books are mostly arranged according to the library classification system of NDC (Nippon Decimal Classification). Some books, however, are arranged to meet the purpose of the rooms. Books concerning art, for example, are placed close to the art studio, those about Japanese culture are placed in front of the Japanese-style room, and those about university exams and career-planning are in front of the seniors' classrooms.

Students are constantly stimulated and challenged by the books that appear before them, thus promoting their own sense of curiosity. The students at Seisho-kaichi cannot avoid books and the learning center when they come to school or move to classrooms. All the classrooms look out on or are very close to the learning center. Thanks to this, students are more easily able to study and access the materials for their research-based learning without worrying about time.

\subsection{Wi-Fi Environment and One Person One Tablet}

Now, I will discuss how Seisho-kaichi integrates ICT devices. In addition to 'the school inside a library' idea, our new school has wireless internet access in the whole school building. Students and teachers can access the internet anywhere. Seisho-kaichi's total floor space is 
3,500 square meters and has 69 internet access points in total, not only in the main building but also in the annex and the gym. Every student has his or her own tablet computer and every teacher has his or her own tablet or laptop. This makes it possible for everyone at school to access the internet, get digital information, or even create digital content anywhere in the school at any time.

All our devices have a newspaper search system easily accessible, so students and teachers can read a national paper and a local paper wherever they are. The devices also have a book-search system. With their tablet or laptop, they can search the book they want to read, check the lending status, and reserve it. Just by sending an e-mail to a school librarian, students can request a new book they have interest in. According a survey by MEXT, among schools in Japan, $65.1 \%$ of junior high and $90.5 \%$ of high schools have already made a database of their books, and $31.8 \%$ of junior high and $90.0 \%$ of high schools have subscribed newspapers (MEXT, 2015, p.8).

\subsection{Active Learning in a New School Space}

Active learning is defined as follows:

Unlike the traditional one-sided lecturing by an instructor, active learning is an instructional method that engages students in the learning process. Thanks to the students' active involvement, they are expected to improve their general ability including cognitive, ethical, and social abilities, and acquire education, knowledge, and experience. Active learning includes discovery learning, problem-based learning, experiential learning, and inquiry learning, and more. Group discussion, debates, and group-work in the classroom are also effective ways to introduce active learning (Central Council for Education, 2012, p.37).

Now l'll introduce one actual example of 'active learning' at our school.

"Let's introduce countries all over the world!" is a social-studies lesson for junior high school $1^{\text {st }}$ grade. What are the differences in conducting this lesson in a conventional Japanese school space and in a newer style space such as our school's? In a conventional school space, students learn about the topic in the classroom, research books in the library, research digital information in the PC room, prepare for presentation in the PC room, and make a presentation in the classroom (the left of Diagram 3). This happens in a closed space or multiple closed spaces, step by step. With our new school space, on the other hand, students can gather analog information through books and newspapers. At the same time and in the same space they can gather digital information through the internet, and finally make presentation materials with their tablet. (the right of Diagram 3) They can do these things at 
the same time because the library, ICT device and classrooms are organically connected.

\section{Conventional School}

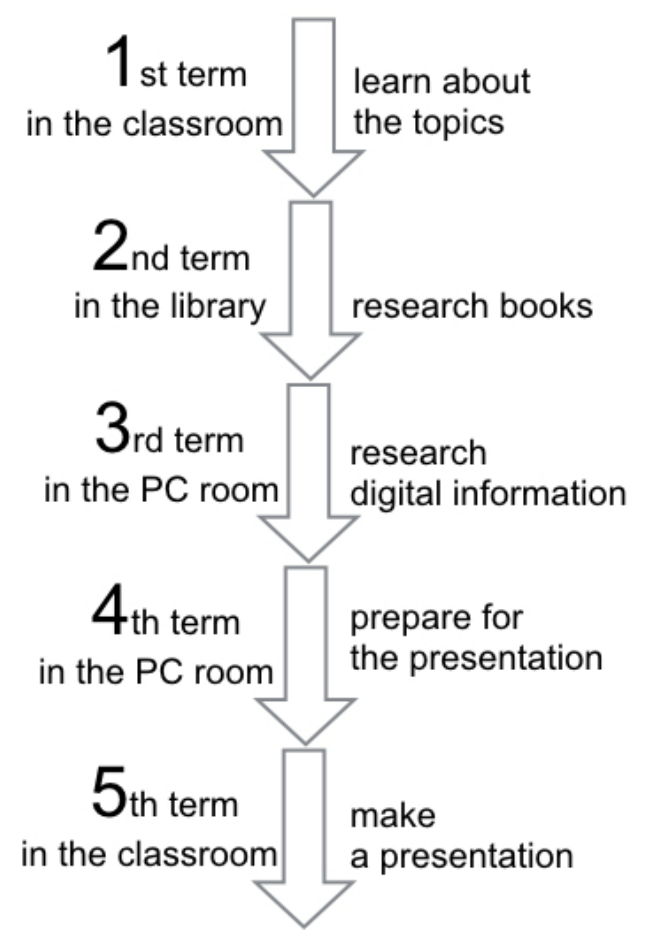

New School

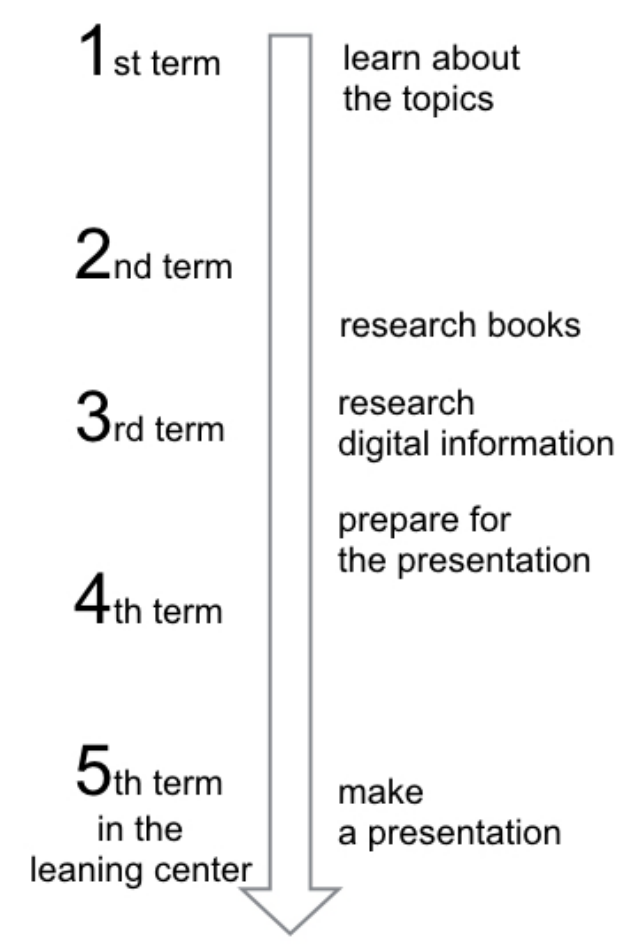

Diagram 3

Students are really used to using their tablet already, as if it were a part of their body. For instance, they can make slideshow presentations without any support from their teachers. In a normal school this wouldn't be the case and teachers would have to explain how to install the applications, how to use them, and how to project their presentation on the whiteboard. At our school, teachers gain lesson time because students are already knowledgeable about ICT.

Sometimes, building up the students' ICT use ability can become a problem. Kansai University Elementary and Junior High School, which opened in 2010, has designed and built a library for ICT environment. However, their students are still not able to use ICT devices easily (Shioya, 2013, p.233). In that school, the problem of how to improve the students' information-use ability still remains.

Communication with peers, teachers, and the outside world is critical in processing and critiquing the information made available to students through these digital and analog tools. Furniture and layout is carefully selected and arranged to best create accessibility to not only the tools, but also so students have easy accessibility to each other. This results in an 
environment where students can naturally share and develop ideas together.

\section{Staff supporting the new type of school space}

Now, I will address how Seisho-kaichi deals with human resources. A school with our special kind of "school inside a library" space usage needs a special management structure. We must manage ICT devices and develop lesson plans using the space efficiently, and manage books too. Only having one library specialist and one ICT specialist is not enough for managing a combined school space. Seisho-kaichi has a management committee of three - a librarian-teacher who qualifies as both a librarian and a librarian-teacher, a librarian, and an ICT coordinator. One becomes the chairperson of the committee and he develops active learning lessons about the research-based learning which needs to research books and digital information. The committee has one meeting every week, and is in charge of managing the school space, developing new lessons, and thinking how to use school space more efficiently.

\section{Awaiting Challenges}

In this article, I introduced the idea of a "school inside a library" that has combined analog and digital tools, and introduced Seisho-kaichi as the practical example. With this space that comes fully-equipped with books and ICT, and with such a space organically connected to classrooms, we can lighten the burden imposed on teachers. Teachers can save preparation and explanation time as the students already know how to use the ICT, and the ICT stimulates students' curiosity. I've also shown that the new type of school space can bring the new age of research-based learning to the students.

Japan's Ministry of Internal Affairs and Communication is now deciding about potentially distributing digital textbooks and setting up wireless LAN in all Japanese elementary, junior high, and high schools by 2020 (MEXT, 2011, p.7). If this happens, the research-based learning that Seisho-kaichi prizes can be done at every school.

One of the biggest obstacles in a mixed analog and digital environment is training personnel who can both efficiently utilize a mixed environment and teach their own subject to students. Even at Seisho-kaichi, according to our survey about how many teachers were using the space effectively, only about one third of them said they actually utilized it to its potential. In order to improve this situation, the school must support teachers much more actively than before. After all, one of the information center's roles is "to meet the needs of 
students and teachers for library materials," so our school has a duty to do so. Educators must also teach students to use a mixed analog and digital environment effectively. Our challenge now is training teachers about teaching with this new school space, and educating students about collecting analog and digital information with books and ICT. Another problem is that the librarian-teacher, school librarian, and ICT coordinator in Seisho-kaichi all have other positions like other school teachers. Seisho-kaichi administrators do not lighten their other duties even with the school's focus on its digital and analog resources. These other duties surely prevent them from focusing on the job of the library. All of these problems comes from a shortage of teachers. Seisho-kaichi is a new private school, and unlike other public schools, teachers are not sent automatically by Tottori City Hall. We need to find a good skillful teacher by ourselves. However, Tottori Prefecture is very small and countryside, not many teachers are willing to come.

There are many problems to solve in our school's library, but we believe we are just at the 'birth pangs' stage. Not many schools in Japan allow teachers such input into integrating the school, library and ICT systems, so we wish to continue building and improving on that we have.

\section{References}

Central Council for Education. (2012). Toward a qualitative change of education at university in order to build a new future: To make a university which can motivate the students to keep learning and develop the ability of active thinking (Report). Retrieved May 28, 2016 from http://www.mext.go.jp/component/b menu/shingi/toushin/ icsFiles/ afieldfile/2012/10/04/1325048 3.pdf

JAPET (Japan Association for Promotion of Educational Technology), Microsoft Japan Co., Ltd.. (2011). A field study on the use of ICT at school: Data Collection. Retrieved May 28, 2016 from http://www2.japet.or.jp/ict-chosa/ict chosa data.pdf

John Dewey. (1915). The School and Society. Translated by Seiichi Miyahara. (1957). Tokyo: Iwanami Shoten, Publishers.

Kyoko Shioya, Tatsuya Horita, Kenichi Kubota. (2013). An examination into the requirements of learning environment in school libraries in order to demonstrate the research-based learning. Annual Report Collection, 29, 230-233. Retrieved May 28, 
2016 from http://ci.nii.ac.jp/els/110009801220.pdf?id=ART0010300811\&type=pdf\& lang=ip\&host $=$ cinii\&order no=\&ppv type $=0 \&$ lang $s w=\& n o=1464697718 \& c p=$

MEXT (Ministry of Education, Culture, Sports, Science and Technology). (2015a). About the status quo of school libraries. Retrieved May 28, 2016 from http://www.mext.go.jp/ b menu/shingi/chousa/shotou/115/shiryo/ icsFiles/afieldfile/2015/10/22/1362875 01.pdf

MEXT. (2015b). The survey on the status quo of School Libraries, fiscal 2014. Retrieved May 28, 2016 from http://www.mext.go.jp/a menu/shotou/dokusho/link/ icsFiles/ afieldfile/2015/12/09/1358454 01.pdf

NIER (National Institute for Educational Policy Research). (2010). PISA 2009 Results: Students On Line: Digital Technologies and Performance. Retrieved May 28, 2016 from http://www.nier.go.jp/kokusai/pisa/pdf/pisa2009 Result Outline.pdf

Parliamentarians on School Libraries, Characters Culture Promotion Organization, Council for proposing fully-equipment to school libraries. (2014). Revised School Library Act Q\&A. Retrieved May 28, 2016 from http://www.gakuto-seibi.jp/pdf/2014leaflet4.pdf

The School Library Act. (1953). Retrieved May 28, 2016 from http://law.e-gov.go.jp/htmldata/ $\underline{\mathrm{S} 28 / \mathrm{S} 28 \mathrm{HO} 185 . \mathrm{html}}$

The Tottori Prefectural Library. (2016). The Promotion Planning of the use of School Library $f$ or education in Tottori: Materials Collection. Retrieved May 28, 2016 from http://www.library.pref.tottori.jp/support-center/【HP 資料編】とつとり学校図書館活 用推進ビジョン.pdf

Yoko Kowata, Eiji Morita, Tomoko Kowata, Yuki Amano, Sunok Kim. (2011). School libraries in Japan and Korea toward new era of ICT: making a comparison of the factoes of school library reform between Japan and Korea. The reports from Welfare Department of Aichi Prefectural University, 60, 1-24. Retrieved May 28, 2016 from http://ci.nii.ac.jp/els/110009059420.pdf?id=ART0009882260\&type=pdf\&lang=ip\&ho

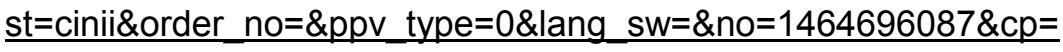


Zensai Oshiro. (2010). Qualification and credentials for employment of the school media specialist in U.S.A. in the 21st century. Library World, 62(1), 2-15. Retrieved May 28, 2016 from http://ci.nii.ac.jp/els/110007819759.pdf?id=ART0009532482\&type=pdf\& lang=ip\&host=cinii\&order no=\&ppv type=0\&lang sw=\&no=1464696315\&cp=

\section{Biographical note}

Principal Auther:

Natsuko OGAWA has worked as a librarian-teacher at Seisho-kaichi Junior and Senior High School in Tottori, Japan since 2014. She graduated from Chuo University. Her professional topic is teaching Japanese.

Co-Author (1):

Hiroki Otazawa is a vice principal and director of ICT management at Seisho-kaichi Junior and Senior High School. He holds a Master's Degree in Engineering from University of Electro-Communications. He has worked at Hitachi,Ltd as a system engineer from 2005 to 2007. Afterwards he designed a lot of children's product e.g. toy, event, museum and more. From 2014 he has been in charge of research-based learning for junior and senior high school students in Seisho-kaichi.

Co-Author (2):

Mikiko HIRAO who graduated from Osaka University and has a bachelor degree. She has experience of teaching at both junior high shool and senior high school for about six years. 